\title{
Apparent nutrient digestibility of carbohydrate (corn) in Cirrhinus mrigala under the influence of chromium chloride hexahydrate
}

\author{
Farkhanda Asad ${ }^{a *}$ (D), Samina Qamer $^{a}$ (D), Asma Ashraf ${ }^{a}$ (D), Azhar Rafique ${ }^{a}$ (D), \\ Zunaira Shaheen ${ }^{a}$ (D), Ayesha Nisar ${ }^{a}$ (D) and Sidra Javaid ${ }^{a}$ (D) \\ ${ }^{a}$ Department of Zoology, Government College University, Faisalabad, Pakistan \\ *e-mail: far_khane@yahoo.com
}

Received: September 17, 2018 - Accepted: April 29, 2019 - Distributed: August 31, 2020

\begin{abstract}
A feeding trial was carried out to assess the effect of dietary chromium supplementation on apparent nutrient digestibility coefficient (\%) of gelatinized and non-gelatinized corn in Cirrhinus mrigala fingerlings for 90 days. Using various levels of chromium chloride hexahydrate six test diets designated as $\mathrm{T} 1\left(\mathrm{G} / 0.0 \mathrm{Cr}_{2} \mathrm{Cl}_{3} 6 \mathrm{H}_{2} \mathrm{O} \mathrm{mg} \mathrm{Kg}{ }^{-1}\right), \mathrm{T} 2\left(\mathrm{NG} / 0.0 \mathrm{Cr}_{2} \mathrm{Cl}_{3} 6 \mathrm{H}_{2} \mathrm{O} \mathrm{mg} \mathrm{Kg}^{-1}\right)$, T3 (G/0.2 $\left.\mathrm{Cr}_{2} \mathrm{Cl}_{3} 6 \mathrm{H}_{2} \mathrm{O} \mathrm{mg} \mathrm{Kg}{ }^{-1}\right)$, T4 (NG/0.2 $\left.\mathrm{Cr}_{2} \mathrm{Cl}_{3} 6 \mathrm{H}_{2} \mathrm{O} \mathrm{mg} \mathrm{Kg}{ }^{-1}\right)$, T5 (G/0.4 $\left.\mathrm{Cr}_{2} \mathrm{Cl}_{3} 6 \mathrm{H}_{2} \mathrm{O} \mathrm{mg} \mathrm{Kg}^{-1}\right)$ and T6 (NG/0.4 $\mathrm{Cr}_{2} \mathrm{Cl}_{3} 6 \mathrm{H}_{2} \mathrm{O} \mathrm{mg} \mathrm{Kg}{ }^{-1}$ ) were prepared. Results showed highest apparent digestibility coefficient (ADC) of nutrients dry matter, crude lipid and gross energy in test diet T5 that was gelatinized and supplemented with chromium $0.4 \mathrm{mg} / \mathrm{Kg}$ while, for crude protein higher value of nutrient digestibility was recorded in T3 test diet $\left(\mathrm{G} / 0.2 \mathrm{Cr}_{2} \mathrm{Cl}_{3} 6 \mathrm{H}_{2} \mathrm{O} \mathrm{mg} / \mathrm{Kg}\right)$. It was concluded that chromium supplementation with gelatinized corn in fish (Cirrhinus mrigala) diet can improve the nutrients digestibility more efficiently.
\end{abstract}

Keywords: dietary chromium, apparent digestibility coefficient, corn and Cirrhinus mrigala.

\section{Digestibilidade aparente de nutrientes oriundos de carboidratos (milho) em Cirrhinus mrigala sob a influência do cloreto de cromo hexa-hidratado}

\section{Resumo}

Um experimento referente à alimentação foi realizado para avaliar o efeito da suplementação dietética de cromo, no coeficiente de digestibilidade aparente do nutriente (\%) do milho gelatinizado e não gelatinizado em alevinos de Cirrhinus mrigala por 90 dias. Usando vários níveis de cloreto de cromo hexa-hidratado, seis dietas testes foram designadas e preparadas como: $\mathrm{T} 1\left(\mathrm{G} / 0,0 \mathrm{Cr}_{2} \mathrm{Cl}_{3} 6 \mathrm{H}_{2} \mathrm{O} \mathrm{mg} \mathrm{Kg}{ }^{-1}\right)$; $\mathrm{T} 2\left(\mathrm{NG} / 0,0 \mathrm{Cr}_{2} \mathrm{Cl}_{3} 6 \mathrm{H}_{2} \mathrm{O} \mathrm{mg} \mathrm{Kg}{ }^{-1}\right)$; $\mathrm{T} 3\left(\mathrm{G} / 0,2 \mathrm{Cr}_{2} \mathrm{Cl}_{3} 6 \mathrm{H}_{2} \mathrm{O} \mathrm{mg} \mathrm{Kg}^{-1}\right)$; $\mathrm{T} 4\left(\mathrm{NG} / 0,2 \mathrm{Cr}_{2} \mathrm{Cl}_{3} 6 \mathrm{H}_{2} \mathrm{O} \mathrm{mg} \mathrm{Kg}^{-1}\right) ; \mathrm{T}^{2}\left(\mathrm{G} / 0,4 \mathrm{Cr}_{2} \mathrm{Cl}_{3} 6 \mathrm{H}_{2} \mathrm{O} \mathrm{mg} \mathrm{Kg}{ }^{-1}\right)$ e T6 (NG/0,4 $\left.\mathrm{Cr}_{2} \mathrm{Cl}_{3} 6 \mathrm{H}_{2} \mathrm{O} \mathrm{mg} \mathrm{Kg}^{-1}\right)$. Os resultados mostraram maior coeficiente de digestibilidade aparente (CDA) em matéria seca de nutrientes, lipídios brutos e energia bruta na dieta teste $\mathrm{T} 5$, que foi gelatinizada e suplementada com cromo 0,4 $\mathrm{mg}$ / $\mathrm{Kg}$; enquanto que para a proteína bruta, foi registrada maior digestibilidade dos nutrientes na dieta teste $\mathrm{T} 3\left(\mathrm{G} / 0,2 \mathrm{Cr}_{2} \mathrm{Cl}_{3} 6 \mathrm{H}_{2} \mathrm{O} \mathrm{mg} / \mathrm{Kg}\right)$. Concluiu-se que a suplementação de cromo com milho gelatinizado na dieta de peixes (Cirrhinus mrigala) pôde melhorar a digestibilidade dos nutrientes de forma mais eficiente.

Palavras-chave: cromo dietético, coeficiente de digestibilidade aparente, milho e Cirrhinus mrigala.

\section{Introduction}

In many parts of the world aquatic food products are essential component of human diet and especially are source of protein. Due to increasing population we are facing shortage of food especially in protein form, fish farming has expanded as substitute cheap source of protein (Zeitoun and Mehana, 2014). During the past four years global annual aquaculture production has been expanding at an average rate of $2.9 \%$ (FAO-FISHSTAT, 2012). Intensive and semi-intensive fish cultures are gaining more importance for production of low cost diet (Khan et al., 2015). For growth and survival of fish species nutrition is most important. Fish meal is a rich source of protein and also containing essential amino acids, low carbohydrates content and fatty acids (Altan and Korkut, 2011). But it is most expensive and not a reliable source. Fish meal can be replaced with other inexpensive sources that would be of different types and originated from plants (Slawski et al., 2013). The trial to improve the feeding strategies is to improve the fish welfare (Silva et al., 2016). Cirrhinus mrigala is commonly called mori, white carp and mrigal. It is one of Indian major carps developed mostly in Southeast Asian nations. It feeds generally on natural vegetation but 
in the absence of natural feed Cirrhinus mrigala feeds on artificial feed (Khan et al., 2015).

To reduce feed cost carbohydrates are utilized in fish feed formulation because carbohydrates are most economical, low cost than lipids and protein and a rich source of energy. According to self -nutrition data, a cup of yellow corn may contain $82 \%$ carbs, $11 \%$ fats, $7 \%$ proteins. But it is inevitable to completely eliminate the fish meal as protein ingredient. However the metabolism of feed being supplying depend upon the source and incorporation of feed ingredients (Chen et al., 2013). Some factors such as dietary level, source or type and gelatinization treatment are responsible for better digestibility of carbohydrates in fishes. From an economic point of view, it is desirable to enhance the nutrient utilization by increasing the carbohydrates use in aqua feeds where they are more readily available and less expensive also than other micro nutrient (Fry et al., 2016). As compared to other fishes major carps have enhanced digestibility for carbohydrates (Kumar et al., 2007). In this experiment corn was utilized as carbohydrate source because it is a rich source carbohydrates and its digestibility and utilization can be enhanced by gelatinization of corn. Gelatinization is a procedure in which corn is treated in the presence of water and heated as a result breaking down of intermolecular bonds occur and swelling of starch granules occur that improves digestibility and palatability (Yengkokpam et al., 2007).

Chromium has various oxidation states from $\mathrm{Cr}^{+2}$ and $\mathrm{Cr}^{+6}$ but in nature mostly trivalent and hexavalent form of chromium are found (NRC, 2005). Chromium chloride hexahydrate reacts with protein and amino acids because it can easily crosse all biological membranes that's why $\mathrm{Cr}^{+6}$ is an powerful oxidizing agent (Pechova and Pavlata, 2007). The purpose of this experimental trial is to utilize low cost diet carbohydrates that improve palatability and digestibility of $C$. mrigala. Chromium choride hexahydrate works as a cofactor for insulin activity and in this experiment it was utilized as food additives which improves metabolism of C. mrigala.

\section{Materials and Methods}

This nutritional trial was performed in research lab, Department of Zoology, Government College University, Faisalabad, Pakistan.

\subsection{Test specie}

C.mrigala specie was selected as experimental fish. Its fingerlings were purchased from fish seed hatchery, Staina road Faisalabad, Pakistan.

\subsection{Acclimatization of experimental fish}

C. mrigala fingerlings were acclimatized for one week and stocked in aquaria having $29 \mathrm{~L}$ water capacity. Throughout acclimatization period C.mrigala fingerlings were fed to satiations on control diet $(32 \% \mathrm{CP})$. By using following standard method (APHA, 1985) water quality parameters such as $\mathrm{pH}$ (7.5-8.5), dissolved oxygen
(5.2-7.3 $\mathrm{mg} / \mathrm{L})$ and temperature $\left(28-31^{\circ} \mathrm{C}\right)$ were noted on daily basis and were found within the acceptable range.

\subsection{Stocking density}

Six hundred fingerlings of equal size were dispersed arbitrarily in six experimental groups with two replicates each. Oxygen pumps with capillary system were used to supply oxygen (5-6 ppm) for proper aeration.

\subsection{Experimental diets}

Fish feed ingredients were purchased from local market. By using corn (gelatinized \& non-gelatinized) with various levels of chromium chloride hexahydrate (0, 0.2 and $\left.0.4 \mathrm{Cr}_{2} \mathrm{Cl}_{3} 6 \mathrm{H}_{2} \mathrm{O} \mathrm{mg} \mathrm{Kg}^{-1}\right)$ six experimental diets were prepared (Table.1). Corn flour was added with almost $80 \%$ water $(\mathrm{v} / \mathrm{w})$ to form it dough. Then place this dough in autoclave for one hour at $120{ }^{\circ} \mathrm{C}$ to attain maximum gelatinization (25\%). By spreading this mass in try positioned it in oven at $60{ }^{\circ} \mathrm{C}$ for an hour. The dried and gelatinized corn flour with all test ingredients were then pulverized to pass through $5 \mathrm{~mm}$ sieve size. All ingredients were mixed thoroughly for $10 \mathrm{~min}$ and fish oil was added gradually while mixing the diet. During mixing 10-12\% water was added to form dough (Lovell, 1989). Dough was then steam conditioned for $10 \mathrm{~min}$. Hand pelletizer was used to prepare pellets of $2 \mathrm{~mm}$ diameter, oven dried for $24 \mathrm{~h}$ at $60{ }^{\circ} \mathrm{C}$ and stored in air tight jars at room temperature until use.

\subsection{Feeding protocol}

Twice a day Cirrhinus mrigala fingerlings were fed on experimental diet at the rate of $4 \%$ live wet body weight. For proximate analysis this nutritional trial was continued for 90 days to collect appropriate amount of fecal matter. Chromic oxide was added at the rate of $1 \%$ as an inert marker. After the feeding period of 2 hours fingerlings were shifted to partitioned aquaria for the collection of fecal matter. By siphoning out fecal matter was collected from each aquarium, then dried at room temperature and stored for proximate analysis.

\subsection{Digestibility studies}

The $\mathrm{ADC}_{\mathrm{s}}(\%)$ of dry matter, ash, crude protein, crude lipid, crude protein, and gross energy was calculated by using following formula (Maynard and Loosli, 1969):

Apparent nutrient digestibility $=100 \times\left[1-\left(\right.\right.$ dietary $\mathrm{Cr}_{2} \mathrm{O}_{3} /$ fecal $\left.\mathrm{Cr}_{2} \mathrm{O}_{3}\right) \times($ fecal nutrient or energy concentration / dietary nutrient or energy concentration)

\subsection{Proximate analysis}

The representative samples of dried feed ingredient (corn), test diets and feces were homogenized by using mortar and pestle separately and were analyzed using standard method (AOAC, 1995) for dry matter (DM), ash, crude lipid (CL) and crude protein (CP). Dry matter contents were measured by drying the samples in oven at $105^{\circ} \mathrm{C}$ for 12 hours; ash analysis was performed in electric muffle furnace at $650{ }^{\circ} \mathrm{C}$ for 6 hours (Eyela-TMF 3100); crude lipid by petroleum 
ether extraction method through Soxtec system (Model HT2, 1045); Crude protein ( $\mathrm{N}$ 6.25) was determined by micro kjeldahl apparatus. Percent $\mathrm{N}$-free extract was calculated by subtracting the sum of $\%$ crude proteins, crude lipids and moisture from 100 i.e. NFE $\%=100-($ crude protein $\%+$ crude fat $\%+$ moisture $\%)$. Gross energy was calculated by using the following formula (Crisan and Sands, 1978, equation 1) :

GE $\left(\mathrm{Kcalg}^{-1}\right)=(5.64 \times$ proteins $\%)+(9.44 \times$ lipids $\%)+(4.11 \times$ NFE $\%)$

Chromium assay: The chromium oxide content in the feeds and fecal matter was estimated by using UV-VIS 2001 Spectrophotometer at $370 \mathrm{~nm}$ absorbance (Divakaran et al., 2002).

\subsection{Statistical analysis}

Highly significant difference among gelatinized and non-gelatinized carbohydrate diets with various levels of chromium chloride hexahydrate was tested by one way analysis of variance (ANOVA) and comparison of means was done by Tukey's Honestly significant difference test and considered significant at $\mathrm{p}>0.05$ (Senedecor, 1991).

\section{Results}

The results for proximate analysis of fish feed, and fecal matter are given in Table 1 and 2 respectively. While apparent nutrient digestibility coefficient (\%) of nutrients dry matter, ash, crude lipid, crude protein and gross energy for test diets is given in Table 3 .

\subsection{Apparent nutrient digestibility coefficient (\%).}

The digestibility of nutrients is not defined accurately in numerous commercial feed stuffs and it is revealed that feed performance and digestibility can be improved with the use of extrusion technology.In this research work we compared the carbohydrate digestibility of two types of corn (G \& NG) at different levels of chromium chloride hexahydrate in fish feed. Obtained results showed maximum apparent nutrient digestibility coefficient (\%) of nutrients dry matter, ash, crude lipid, crude protein and gross energy

Table 1. Proximate nutrient analysis of fish test diets and estimation of chromic oxide $\left(\mathrm{Cr}_{2} \mathrm{O}_{3}\right) \%$.

\begin{tabular}{lcccccc}
\hline \multicolumn{1}{c}{ Nutrients } & T1 (G) & T2 (NG) & T3 (G) & T4 (NG) & T5 (G) & T6 (NG) \\
\hline Dry matter (\%) & 98 & 96 & 97 & 98 & 99 & 98 \\
Ash (\%) & 20.10 & 21.61 & 22.79 & 35.13 & 25.60 & 28.00 \\
Crude lipid (\%) & 20 & 19 & 24 & 26 & 32 & 22 \\
Crude protein (\%) & 39.06 & 35.93 & 31.25 & 37.5 & 35.93 & 32.81 \\
Chromic oxide (\%) & 0.97 & 0.97 & 0.98 & 0.96 & 0.97 & 0.96 \\
Gross energy (Kcal/g) & 569.04 & 550.79 & 574.4 & 598.73 & 632.41 & 570.27 \\
\hline
\end{tabular}

Table 2. Proximate nutrient analysis of fish fecal matter and estimation of chromic oxide $\left(\mathrm{Cr}_{2} \mathrm{O}_{3}\right) \%$.

\begin{tabular}{lcccccc}
\hline & \multicolumn{7}{c}{ Fecal matter } \\
\hline \multicolumn{1}{c}{ Nutrients } & T1 (G) & T2 (NG) & T3 (G) & T4 (NG) & T5 (G) & T6 (NG) \\
\hline Dry matter (\%) & 88.02 & 92.05 & 88 & 92 & 91 & 91 \\
Ash (\%) & 17.19 & 19.31 & 21.72 & 31.62 & 24.50 & 24.12 \\
Crude lipid (\%) & 10.15 & 11.05 & 9.5 & 9 & 11.5 & 10.5 \\
Crude protein (\%) & 34.90 & 32.40 & 25.78 & 29.68 & 34.37 & 31.22 \\
Chromic oxide (\%) & 1.29 & 1.20 & 1.42 & 1.31 & 1.57 & 1.48 \\
Gross energy(Kcal/g) & 469.17 & 486.79 & 451.75 & 471.5 & 487.88 & 477.70 \\
\hline
\end{tabular}

Table 3. Apparent nutrient digestibility coefficient (\%) of test diets used in trial.

\begin{tabular}{lccccc}
\hline \multicolumn{1}{c}{ Sr.No } & Dry matter & Ash & Crude lipid & Crude protein & Gross energy \\
\hline T1 (G) & $34.00 \pm 1.00^{\mathrm{C}}$ & 37.00 & $63.00 \pm 3.00^{\mathrm{BC}}$ & $34.0 \pm 1.00^{\mathrm{AB}}$ & $39.00 \pm 2.00^{\mathrm{BC}}$ \\
T2 (NG) & $24.00 \pm 0.00^{\mathrm{D}}$ & 36.00 & $54.00 \pm 2.00^{\mathrm{C}}$ & $28.00 \pm 1.00^{\mathrm{B}}$ & $30.00 \pm 1.00^{\mathrm{C}}$ \\
T3 (G) & $38.00 \pm 1.00^{\mathrm{BC}}$ & 35.00 & $74.00 \pm 1.00^{\mathrm{AB}}$ & $44.00 \pm 4.00^{\mathrm{A}}$ & $47.00 \pm 2.00^{\mathrm{AB}}$ \\
T4 (NG) & $33.00 \pm 0.00^{\mathrm{C}}$ & 39.00 & $76.00 \pm 3.00^{\mathrm{AB}}$ & $43.00 \pm 1.00^{\mathrm{A}}$ & $44.00 \pm 1.00^{\mathrm{AB}}$ \\
T5 (G) & $45.00 \pm 2.00^{\mathrm{A}}$ & 43.00 & $79.00 \pm 2.00^{\mathrm{A}}$ & $43.00 \pm 3.00^{\mathrm{A}}$ & $54.00 \pm 3.00^{\mathrm{A}}$ \\
T6 (NG) & $42.00 \pm 1.00^{\mathrm{AB}}$ & 45.00 & $70.00 \pm 4.00^{\mathrm{AB}}$ & $40.00 \pm 1.00^{\mathrm{AB}}$ & $47.00 \pm 2.00^{\mathrm{AB}}$ \\
\hline
\end{tabular}

Means sharing similar letters are statistically non-significant $(\mathrm{P}>0.0)$. 
in experimental group that was fed on diet supplemented with gelatinized corn and chromium chloride hexahydrate.

The apparent nutrient digestibility coefficient (ADC) of nutrient dry matter was found highest for the experimental group-T5 $\left(45.00 \pm 2.00^{\mathrm{A}}\right)$ and lowest value was recorded for T2 $\left(24.00 \pm 0.00^{\mathrm{D}}\right)$. While apparent ash digestibility was found maximum in experimental group-T6 (45.00). In case of nutrient crude lipid ADC was found highest in experimental group-T5 $\left(79.00 \pm 2.00^{\mathrm{A}}\right)$ and lowest values was observed for T2 $\left(54.00 \pm 2.00^{\mathrm{C}}\right)$. For crude protein apparent nutrient digestibility was recorded highest in experimental group-T3 $\left(44.00 \pm 4.00^{\mathrm{A}}\right)$ and lowest for group- T2 $\left(28.00 \pm 1.00^{\mathrm{B}}\right)$. The highest value of apparent digestibility coefficient for gross energy was found maximum for group-T5 $\left(54.00 \pm 3.00^{\mathrm{A}}\right)$ and minimum for group-T2 $\left(30.00 \pm 1.00^{\mathrm{C}}\right)$.

\section{Discussion}

This feeding trial revealed that apparent nutrient digestibility coefficient values for all nutrients (dry matter, ash, crude lipid, crude protein and gross energy) were maximum in experimental groups that were treated with diets supplemented with gelatinized corn and chromium chloride hexahydrate. Inclusion of gelatinized corn improves the digestibility and utilization of fish feed. Some factors are responsible for better digestibility of carbohydrates i.e. type of carbohydrate, level of gelatinization and dietary addition level (Mohapatra et al., 2003). The apparent digestibility coefficient (ADC) of dry matter was found maximum in experimental group- $\mathrm{T} 5\left(\mathrm{G} / 0.4 \mathrm{Cr}_{2} \mathrm{Cl}_{3} \cdot 6 \mathrm{H}_{2} \mathrm{Omg} / \mathrm{kg}\right)$. It may be due to the reason that gelatinized corn increased utilization of feed and as a result better growth attained that improved dry matter in fish body. These results are in favor of Yengkokpam et al. (2007) who stated that apparent digestibility coefficient of dry matter improved by using gelatinized carbohydrates as compared to non-gelatinized carbohydrates. While Mohapatra et al. (2003) reported that apparent dry matter digestibility was greater in those experimental groups that were fed on non-gelatinized corn.

Highest value of ADC for ash was recorded in experimental group-T6. Liu et al. (2010) reported that Cr-pic had no beneficial effects on ash deposition in fish body meat. However, contrary results of our finding were observed by Asad et al. (2014) who concluded maximum ash value of ADC for non-gelatinized corn. Apparent nutrient coefficient for crude lipid was found highest in group-T5 $\left(\mathrm{G} / 0.4 \mathrm{Cr}_{2} \mathrm{Cl}_{3} \cdot 6 \mathrm{H}_{2} \mathrm{Omg} / \mathrm{kg}\right)$. These results are in accordance with Shahzad et al. (2006) who reported that lipid digestibility was highest for corn as compared to feather and wheat meal. However, dissimilar conclusions were observed by Asad et al. (2014) who stated highest ADC of lipid in non-gelatinized corn as compared to gelatinized corn. Diet containing rich source of carbohydrates maximize lipogenic enzyme activity in omnivorous fish and as a result maximum lipid deposit in various tissues (Yengkokpam et al., 2007). Apparent protein digestibility was positively correlated with gelatinized feed because maximum value was recorded for experimental group-T3 (G/ $\left.0.2 \mathrm{mg} \mathrm{kg}^{-1}\right)$. Similar results were reported by Shahzad et al. (2006) who found highest apparent digestibility coefficient of crude protein in corn meal. Gelatinization of corn enhanced digestibility of feed which result improved protein profile of fish.In case of gross energy maximum value of apparent digestibility coefficient was recorded for group- $\mathrm{T} 5\left(\mathrm{G} / 0.4 \mathrm{Cr}_{2} \mathrm{Cl}_{3} \cdot 6 \mathrm{H}_{2} \mathrm{Omg} \mathrm{kg}{ }^{-1}\right)$. However, contradictory results were observed by Asad et al. (2014) who reported maximum value of ADC for gross energy in non-gelatinized corn. It might be due to variation in feed ingredients or addition of chromium chloride hexahydrate.

\section{Conclusion}

From trial it was concluded that inclusion of dietary chromium (chromium chloride hexahydrate) with gelatinized corn in fish feed of Cirrhinus mrigala improved digestibility coefficient of dry matter, ash and crude lipid and gross energy at level of $0.4 \mathrm{mg} \mathrm{kg}^{-1}$ chromium chloride hexahydrate and improved digestibility coefficient of crude protein at $0.2 \mathrm{mg} \mathrm{kg}^{-1}$ level. However, additional work is needed to investigate the most appropriate amount of chromium chloride hexahydrate with varying gelatinized levels of other carbohydrate sources for more sustainable aquaculture production.

\section{References}

ALTAN, O. and KORKUT, A.Y., 2011. Appearent digestibility of plant protein based diets by European sea bass Dicentrar chuslabrax L., 1758. Turkish Journal of Fisheries and Aquatic Sciences, vol. 11, no. 1. http://dx.doi.org/10.4194/trjfas.2011.0112.

AMERICAN PUBLIC HEALTH ASSOCIATION -APHA, 1985. Standards methods for the examination of water and waste water 16th ed. Washington, DC: APHA.

ASAD, F., QAMER, M. and TAHIR, N., 2014. Apparent nutrient digestibility assessment and influence of gelatinized and non-gelatinized corn starch based diet in Labeo rohita. Journal of Aquaculture Research \& Development, vol. 5, no. 5. http:// dx.doi.org/10.4172/2155-9546.1000250.

ASSOCIATION OF OFFICIAL ANALYTICAL CHEMISTS AOAC, 1995. Official methods of analysis. 15th ed. Washington, DC: Association of Official Analytical Chemists, 1094 p.

CHEN, M.Y., YE, J.D., YANG, W. and WANG, K., 2013. Feed utilization, metabolic and growth responses to different ratios of feed diets in Nile tilapia (Oreochromis niloticus). Asian-Australasian Journal of Animal Sciences, vol. 26, no. 8, pp. 1160-1171. http:// dx.doi.org/10.5713/ajas.2013.13022. PMid:25049897.

CRISAN, E.V. and SANDS, A., 1978. Nutritional Value. New York: Academic Press, pp. 137-168.

DIVAKARAN, S., LEONARD, G.O. and IAN, P.F., 2002. Note on the methods for determination of chromic oxide in shrimp feeds. Journal of Agricultural and Food Chemistry, vol. 50, pp. 464-467.

FOOD AND AGRICULTURE ORGANIZATION OF THE UNITED NATIONS - FAO-FISHSTAT, 2012. FAO Fisheries department, fishery information, data and statistics unit. Fish stat, a tool for fishery statistical analysis, Release 2.0.0. Global 
capture fisheries production 1950-2010, Global aquaculture production 1950-2010, Global commodities production and trade 1978-2009. Rome: FAO.

FRY, P.J., DAVID, C.L., GRAHAM, K., PAUL, C.W., PEDER, M.E., KEEVE, E.N. and ROBERT, S.L., 2016. Environmental health impacts of feeding crops to farmed fish. Journal of Environmental International, vol. 91, pp. 201-214. http://dx.doi. org/10.1016/j.envint.2016.02.022. PMid:26970884.

KHAN, J.K., KHAN, N., RASOOL, F., ULLAH, S. and HASSAN, S., 2015. Apparent digestibility of selected plant based ingredients and their impacts on body composition of Mori, Cirrhinus mrigala (Hamilton, 1882). Global Veterinaria, vol. 15, no. 6, pp. 536-540.

KUMAR, V., SAHU, N., PAL, A. and KUMAR, S., 2007. Immuno modulation of Labeo rohita juveniles due to dietary gelatinized and non-gelatinized starch. Fish \& Shellfish Immunology, vol. 23, no. 2, pp. 341-353. PMid:17383896.

LIU, T., WEN, H., JIANG, M., YUAN, D., GAO, P., ZHAO, Y. and LIU, W., 2010. Effect of dietary chromium picolinate on growth performance and blood parameters in grass carp fingerling, Ctenopharyngodon idellus. Fish Physiology and Biochemistry, vol. 36, no. 3, pp. 565-572. PMid:19459058.

LOVELL, R.T., 1989. Nutrition and feeding of fish. New York: Van Nostrand Reinhold. Feed formulating and processing. 260 p.

MAYNARD, L.A. and LOOSLI, J.K., 1969. Animal NutrBion. 6th ed. New York: McGraw Hill.

MOHAPATRA, M., SAHU, N. and CHAUDHARI, A., 2003. Utilization of gelatinized carbohydrate in diets of Labeo rohita fry. Aquaculture Nutrition, vol. 9, no. 3, pp. 189-196. http://dx.doi. org/10.1046/j.1365-2095.2003.00243.x.
NATIONAL ACADEMIC PRESS - NRC, 2005. Mineral Tolerance of Animals. Washington: National Academic Press.

PECHOVA, A. and PAVLATA, L., 2007. Chromium as an essential nutrient: a review. Veterinarni Medicina, vol. 52, pp. 1-18.

SENEDECOR, G.W.C., 1991. Statistical methods. 8th ed. Ames: Iowa State University Press, $503 \mathrm{p}$

SHAHZAD, K., SALIM, M. and ASAD, F., 2006. Evaluation of apparent digestibility coefficient of corn, wheat and feather meal for Labeo rohita. Pakistan Journal of Zoology, vol. 38, no. 2, pp. 125 .

SILVA, F.R., ALEXENDER, K. \& FRANCISCO, J.S.V., 2016. Dietray self-selection in fish; a new approach to studying fish nutrition and feeding behavior. Reviews in Fish Biology and Fisheries, vol. 26, no. 1, pp. 39-51.

SLAWSKI, H., NAGEL, F., WYSUJACK, K., BALKE, D.T., FRANZ, P. and SCHULZ, C., 2013. Total fish meal replacement with canola protein isolate in diets fed to rainbow trout (Oncorhynchus mykiss W.). Aquaculture Nutrition, vol. 19, no. 4, pp. 535-542. http://dx.doi.org/10.1111/anu.12005.

YENGKOKPAM, S., SAHU, N., PAL, A., MUKHERJEE, S. and DEBNATH, D., 2007. Gelatinized carbohydrates in the diet of Catla catla Fingerlings: effect of levels and sources on nutrient utilization, body composition and tissue enzyme activities. Asian-Australasian Journal of Animal Sciences, vol. 20, no. 1, pp. 89-99. http://dx.doi.org/10.5713/ajas.2007.89.

ZEITOUN, M.M. and MEHANA, E.E., 2014. Impact of water pollution with heavy metals on fish health: Overview and Updates. Global Veterinaria, vol. 12, no. 2, pp. 219-231. 